\title{
Uçuş Deneyiminde Müşterilerarası Etkileşimler: Kritik Olaylar Tekniği ile Bir Durum Analizi
}

\author{
Customer-to-Customer Interactions on Flight Experience: A Situation Analysis by Critical Incidents Technique
}

\author{
Meltem CABER* \\ * Doç. Dr., Akdeniz Üniversitesi, Turizm Fakültesi, Turizm Rehberliği Bölümü, Dumlupınar Bulvarı, 07058, Kampüs, Antalya. \\ E-posta: meltemcaber@akdeniz.edu.tr
}

MAKALE BILGILERI

Makale ișlem bilgileri:

Gönderilme tarihi: 23 Haziran 2016

Düzeltme: 5 Eylül 2016

Kabul: 7 Ekim 2016

Anahtar sözcükler: Müşterilerarası etkileşim, Kritik olaylar tekniğ i, Uçuş deneyimi.

ARTICLE INFO

Article history:

Submitted: 23 June 2016

Resubmitted: 5 September 2016

Accepted: 7 October 2016

Key words: Customer interactions, Critical incidents technique, Flight experience. öz

Turizm sektöründe iș süreçleri ve hizmet sunumları personel, müșteri ve çevre arasındaki yakın ilișki ve etkileşimler ile gerçekleştirilmektedir. Illgili alanyazında personel ve müşteri arasındaki iliş̧ileri ele alan çok sayıdaki çalışmanın aksine, müşterilerin diğer müşterilerle olan etkileşimini inceleyen araştırmaların sayısı halen sınırlıdır. Bu çalıșmada havayolu ișletmeleri örneğinde müşterilerin uçuş deneyimlerini olumlu veya olumsuz yönde etkileyen ve diğer müșterilerden kaynaklanan kritik olaylar tespit edilmeye çalıșılmıștır. Bu amaçla Antalya şehir turuna katılan 206 yerli turistten açık-uçlu soru formu ile $\mathbf{4 7 8}$ adet kritik olay elde edilmiştir. Bu olaylar önce olumlu ve olumsuz olmak üzere iki kategoriye ayrılmıs, daha sonra her iki kategoride yer alan kritik olayların nitelikleri uçuş deneyimindeki 'biniș', 'uçuş' ve 'iniș' seklindeki üç temel sürece bağlı olarak karşılaştırılmıştır. Elde edilen sonuçlar, olumsuz müşterilerarası etkileşimlerin, olumlu etkileşimlerden daha fazla sayıda olduğunu göstermektedir. Bu nedenle, havayolu işletmelerinin özellikle olumsuz müşterilerarası etkileşimleri tespit etmeleri ve yaşanan sorunları çözüme kavuşturmaları işletme başarıları açısından gereklidir.

\begin{abstract}
Work processes and service offerings in tourism sector are performed by close relationships and interactions among the staff, customer and environment. In the related literature, in spite of numerous studies about the staff and customer interactions, number of the research that investigates the interactions of the customers with other customers is still limited. In this study, it was aimed to identify the critical incidents which positively or negatively impact customers' flight experience and are originated from other customers in the sample of airway companies. With this purpose, 478 critical incidents were obtained by an open-ended style questionnaire from 206 domestic tourists who had participated Antalya city tour. These incidents were firstly categorized as positive and negative; then the characteristics of the incidents in both categories were compared to each other by relying on three main process of flight experience, which are 'boarding', 'flight' and 'landing'. The obtained results showed that number of the negative customer interactions was higher than positive interactions. Thus, it is necessary for airway companies to identify negative customer interactions particularly and to solve the occurred problems for their business success.
\end{abstract}

\section{GíRiş}

Pine ve Gilmore (1999) hizmet işletmelerinin 'tedarik odaklı' yaklaşımları terk ederek, müşteri hafızasında yer eden tüketim tecrübeleri yaratmaya odaklanmaları gerektiğini savunmuş ve hizmet işletmelerinin birer tiyatro gibi 'sahneledikleri' performanslar ile 'deneyimsel ekonomi'yi yarattıklarına dikkat çekmiştir. Buna göre işletmeler, müşterilere değerli, yüksek kaliteli, unutulmaz ve memnuniyet yaratan hizmetler sunmak zorundadırlar. Özellikle turizm işletmeleri tarafından sunulan hizmetlerin müşteriler üzerinde duygusal ve deneyimsel reaksiyonlar yaratma potansiyelleri yüksektir (Otto ve Ritchie 1996).

Esasen turizm faaliyetleri esnasında yaşanan çok sayıda ve yakın sosyal etkileşimin müşterileri ya 'sosyal kolaylaştırma' (social facilitation) olarak adlandirılan olumlu deneyimlere (kuyrukta beklerken başkalarıla sohbet etmenin bekleme toleransını arttırması, grup halindeki müşterilerin yalnız kişilere kıyasla yeme-içme, alışveriş merkezi gibi işletmelerde geçirdikleri ortalama sürenin ve yaptıkları aktivitelerin daha fazla 
olması gibi) ya da 'sosyal müdahale' (social intrusion) adı verilen olumsuz deneyimlere (sigara içenlerin, yüksek sesle konuşanların, kalabalığın yol açtığı rahatsızlık hissi gibi) sevk edeceği öngörülmektedir (Baker ve Cameron 1996).

Araştırmacılar turizm deneyimine yön veren çeşitli sosyal etkileşimleri işletme, personel ve diğer müşteriler olmak üzere üç boyutta ele alarak, müşteri davranışlarını açıklamaya çalışmaktadırlar. Ancak mevcut alanyazında müşteri-personel etkileşimlerini ele alan çok sayıdaki çalışmaya karşılık, müşterilerarası etkileşimleri inceleyen çalışmaların sayısı sınırlıdır (Zhang, Beatty ve Mothersbaugh 2010; Yoo, Arnold ve Frankwick 2012). Mevcut araştırma sonuçları ise müşterilerin diğer müşterilerle olan olumlu ve olumsuz etkileşimlerinin hizmet işletmesine yönelik değerlendirmeleri (Mourali 2003; Miao ve Mattila 2013), memnuniyeti (Wu 2007; Huang 2008) ve tekrar gelme/satın alma niyetini (Martin ve Pranter 1989) doğrudan etkilediğini göstermektedir. Bu açıdan Palmer'ın da (2005) belirttiği gibi müşterilerarası etkileşimleri anlayabilmek; diğer müşterileri olumlu veya olumsuz şekilde etkileyen müşterilerin başlica niteliklerini belirleyebilmek önemlidir. Bu sayede işletmeler açısından gerçekleştirilmesi istenen veya beklenilen müşteri davranışlarının yönetilebilmesi ve olumlu müşterilerarası etkileşimlerden fayda sağlanabilmesi mümkündür.

Bu çalışmada, havayolu işletmeleri örneğinde bir durum analizi yapılarak müşterilerin uçuş deneyimlerini etkileyen başlıca müşterilerarası etkileşimlerin kritik olaylar yöntemi vasıtasıyla tespit edilmesi amaçlanmıştır. Bu bağlamda, ilk olarak ilgili alanyazına ait bir özet sunulmuştur. İzleyen bölümlerde araştırma yöntemi açıklanarak elde edilen sonuçlar tartışılmıştır. Son olarak çalışmanın başlıca kısıtları ve ileride yapılabilecek araştırmalara dair bazı öneriler sunulmuştur.

\section{ALANYAZIN TARAMASI}

\section{Müşterilerarası Etkileşimler}

1970'li yılların ortasından itibaren müşteri hizmet algısı üzerinde diğer müşterilerin davranışlarının da etkili olduğu anlaşılmaya başlanmıştır (Nicholls 2011). Hizmet pazarlaması alan- yazınında müşterilerarası etkileşimleri ele alan ve açıklayan başlıca iki model öne çıkmaktadır. Bunlardan ilki Langeard, Bateson, Lovelock ve Eiglier'in (1981) Hizmetlerin Üretimi Modeli'dir (Servuction Model). Model, işletmelerin ön ve arka planlarında üretilen birbirlerini destekler yapıdaki mal ve hizmetlerin her aşamasında işletme, personel, müşteri ve müşterilerarası birçok etkileşimin gerçekleştiğini yansıtmaktadır. Bu modele göre, müşterilerin genel hizmet alg1sı hem arka planda üretilen mal ve hizmetlerden hem de ön planda görülen fiziki çevre, personel ve diğer müşterilerden etkilenerek şekillenmektedir. Temel olarak hizmet işletmelerinde müşteri-personel, müşteri-hizmet ortamı ve müşterilerarası olmak üzere üç farklı etkileşim şeklinin söz konusu olduğu kabul edilmektedir (Wu 2008).

İkinci model, Bitner'in (1992) öne sürdüğü Hizmet Alanı Modeli'dir (Servicescape Model). Bu yaklaşımda hizmet işletmelerinde bulunan müşteri, personel ve çevre faktörleri arasındaki ilişkinin ve etkileşimin önemi vurgulanmakta; hem müşterilerin hem de hizmet işletmelerindeki personelin izlenimlerini ve davranışlarını etkileyen çevre faktörleri ele alınmaktadır. Modele göre, hizmet çevresi sadece fiziki unsurlardan oluşmamakta, aynı zamanda genel atmosferi oluşturan insanları da kapsamaktadır. Bu nedenle sosyal etkileşimler çevresel uyaranların şekil almış hallerinden ziyade, müşteri-personel-çevre arasındaki ilişkilerin bir çıktısı olarak görülmelidir (Tombs ve McColl-Kennedy 2003). Günümüzde müşterilerin diğer müşterilerle olan etkileşimleri ve ilişkileri turizm alanyazını açısından bir araştırma alanı oluşturmaktadır. Uluslararası alanyazında müşteri-müşteri etkileşimi (customer-tocustomer interaction: $\mathrm{CCI}$ ) veya diğer müşterilerin etkisi (influence of other customers) şeklinde kullanılan ve bu çalışmada 'müşterilerarası etkileşim' şeklinde ele alınan kavram; aynı zaman ve ortamda hizmet alan müşteriler arasında gerçekleşen "karşılıklı konuşmalar, konumsal değişmeler, tavırlar, fiziki temas ve benzeri gözlemlenebilir davranışlara yol açabilen sosyal bir süreç" olarak tanımlanmaktadır (Davies, Baron ve Harris 1999).

Müşterilerarası etkileşim kavramı hizmet sektörünün birçok alanında söz konusu olan yakın 
sosyal ilişkilerden kaynaklanan ve müşterileri hizmet kalitesi, işletme imajı, davranışsal niyet gibi önemli değişkenleri etkileyen bir konudur. Nitekim Söderlund'un (2011) yaptığ 1 deneysel bir araştırmada katılımcıların geliştirilen senaryoya bağlı olarak sırasıyla bir restoranda yemek yemeleri, bir mağazayı gezmeleri ve sinemaya gitmeleri sağlanmıştır. Bu çalışma sonucunda aynı ortamda bulunan müşterilerin diğer müşterilerin bir işletmeye yönelik genel değerlendirmeleri üzerinde etki sahibi oldukları görülmüştür. Bir başka çalışmada, yakın sosyal ilişkilerin söz konusu olduğu kuaför salonlarını inceleyen Moore, Moore ve Capella (2005), müşteri sadakati ve tavsiye etme davranışı üzerinde rol oynayan müşterilerarası ilişkilerin atmosferden etkilendiğini göstermiştir. Huang (2008) Kuzey Tayvan'daki bir alışveriş merkezinde gerçekleştirdiği çalışmada, katılımcıların alışveriş deneyimleri üzerinde başka müşterilerden kaynaklanan olumsuz olayların etkisini araştırmıştır. Elde ettiği sonuçlar müşterilerin hizmet değerlendirmelerinin sadece diğer müşterilerin olumsuz davranışlarından etkilenmediğini, aynı zamanda bu tür davranışlar karşısında işletme personelinin gösterdiği reaksiyonun da müşteriler açısından önem taşıdığını yansitmiştır.

Yi, Gong ve Lee (2013) bir işletmeye yönelik yüksek vatandaşlık davranışında bulunan müşterilerin diğer müşterileri etkileyerek, onları da benzer davranışlara sevk edebileceğini göstermiştir. McGrath ve Otnes (1995), gözlem, görüşme ve katılımcıyla birlikte alışveriş gibi teknikler kullanarak, farklı hizmet alanlarında diğer müşterilerin etkisini belirlemeye çalışmıştır. Elde edilen sonuçlar etkileşimde bulunulan müşteri gruplarının üçe ayrılabileceğini (yardım arayan, takip eden, zarar veren) göstermiştir. Yakın bir zamanda Brocato, Voorhees ve Baker (2012) tarafından müşterilerarası etkileşimleri ölçümleyebilmek amacıyla geliştirilmiş olan üç boyutlu (benzerlik, fiziki görünüş ve uygun davranış) 'Diğer Müşteri Alg1s1' (Other Customer Perception: OCP) ölçeği, müşterilerarası etkileşimlerin hizmet kalitesi algısını ve davranışsal niyeti belirlediğini göstermiştir.

\section{Turizm İşletmelerinde Müşterilerarası Etkileşimler}

Hizmet pazarlaması ile ilgili alanyazında 1970'li yıllardan beri ele alınan müşterilerarası etkileşim kavramının 1990'lı yıllardan itibaren turizm işletmeciliği alanına uyarlanmaya başlandığg ve gerçekleştirilen çalışmaların sayısında artış yaşandığ görülmektedir. Örneğin, Bitner, Booms ve Mohr'ın çalışmasında (1994) havayolu, otel ve yeme-içme işletmelerinde müşterileri rahatsız eden olayların \%22'sinin diğer müşterilerden kaynaklandığı görülmüştür. Grove ve Fisk (1997) tarafından yapılan bir araştırmaya katılan 486 kişiden 276 'sı $(\% 56,8)$ ise kendileri ile aynı yerde ve zamanda hizmet alan müşterilerin bir turizm aktivitesinden edindikleri memnuniyeti ya da memnuniyetsizliği doğrudan etkilediğini belirtmişlerdir. Bu sonuçlar, turizm sektörü ve bu sektörde faaliyet gösteren işletmeler açısından müşterilerarası etkileşimin yapısının ve etkilerinin anlaşılarak, stratejik amaçlara göre yönlendirilmesi gerektiğini göstermektedir.

Turizm alanyazınında yer alan sınırlı sayıdaki araştırmalardan biri, Wu'nun (2007) seyahat esnasında müşterilerarası etkileşim algısını şekillendiren başlıca olayları tespit etmek amacıyla yaptığı çalışmadır. Elde edilen sonuçlar altı faktörün (protokol ve sosyal içerikli olaylar; şiddet veya hoşnutsuzluk yaratan olaylar; yakışıksız davranışlar; terbiyesizlik; saygısızlık) bu hususta rol oynadığını göstermiştir. Aynı araştırmanın bulgularına göre şiddet veya hoşnutsuzluk yaratan olaylar müşteri memnuniyetini olumsuz yönde etkilerken, yakınlık kurulan kişilerin yapmış olduğu değerlendirmeler memnuniyeti olumlu yönde etkilemektedir.

Bir başka çalışmada, Nicholls (2011) uzman görüşlerine dayanarak konaklama işletmelerinde gerçekleşen müşterilerarası etkileşimlerde kültürel farklılıklardan kaynaklanan olumlu ve olumsuz hususları kavramsal açıdan ele almıştır. İlgili araştırmacı, otel yöneticilerinin müşterilerarası kültürel farklılıkların olumsuzluklara yol açacağına inandıklarını tespit etmiştir. Ancak otel yöneticileri müşterilerarası etkileşimlerin ve kültürel farklılıkların ortaya çıkaracağı bazı olumlu sonuçları iyi bir şekilde yönetmeleri halinde başarılı olabileceklerini de belirtmişlerdir. Kim ve Lee 
(2012) ise yeme-içme işletmelerinde diğer müşterilerin etkisini senaryoya dayalı bir araştırma ile inceleyerek, 'diğer müşteriler' kavramının altı özellikten oluştuğunu (yaş, cinsiyet, görünüm, giyim, sayı ve kamusal davranış) ortaya koymuştur. Ayrıca ilgili araştırmacılar işletmelerin müşteri memnuniyetini sağlamak için farklı motivasyona veya algılanan riske sahip müşteriler için özel stratejiler geliştirmesi gerektiğini belirtmiştir. Görüldügü üzere turizm alanyazınında müşterilerarası etkileşimler henüz seyahat, konaklama ve yeme-içme işletmelerinde yapılmış sınırlı sayıdaki çalışmaya dayanmaktadır. Bu nedenle, ilgili alanyazında müşterilerarası etkileşimlere yönelik akademik ilginin ve gerçekleştirilen araştırmaların sayısının artması, turizm sektörünün gelişimine önemli katkılar yapabilecektir.

\section{ARAŞTIRMA YÖNTEMI}

\section{Kritik Olaylar Tekniği}

Kritik olaylar tekniği, genellikle bir sistem içerisinde herhangi bir sorun meydana geldiğinde, bunu ortaya çıkaran başlıca nedenlerin ortaya konulması amaciyla kullanılmaktadır (The Usability Body of Knowledge 2012). Bu teknik, aynı zamanda sorunun ortaya çıkmasını önleyen, kayıpları veya hataları azaltan yan unsurların tespiti için de yararlıdır. Araştırmacılar kritik olaylar tekniğini çoğunlukla hizmet kalitesinin iyileştirilmesi, hataların telafisi, personel davranışının müşteriler üzerindeki etkisinin tespiti gibi konularda kullanmışlardır (Öztürk 2000).

Başarılı bir kritik olaylar tekniği uygulaması yapılabilmesi için birtakım prensiplere uyulmaS1 şarttır. Flanagan'a (1954) göre bu prensipler: hazırlık aşamasında sadece istenen niteliklere sahip katılımciların hedef alınması; veri toplama aşamasında açık ve anlaşılır bir biçimde katılımcılara yöneltilmiş olan araştırma sorusuna odaklanılması; analiz aşamasında kritik olayların araştırmacılar tarafından tarafsız bir bakış açısıyla incelenerek kategorilerin oluşturulması ve bu kategorilerin en az iki bağımsız araştırmacı tarafından teyit edilmesi şeklinde sıralanabilir. Araştırma katılımcıları belli bir deneyimi veya sorunu yaşamış kişilerden, bu sorunun yaşandığını gözlemleyen diğer kişilerden veya işletmelerin ilgili bölümde çalışan uzman personelden oluşabilmektedir (The Usability Body of Knowledge 2012). Bu kişilerin yanı sıra paydaş işletmelerin veya denetim kuruluşlarının verdiği bilgilerden de yararlanılabilmektedir. Mülakat, form doldurma veya grup görüşmeleri yoluyla katılımc1ların soruna veya yaşanan deneyime dair detaylı görüşleri elde edilerek, toplanan bilgiler bir veritabanında veya yapılandırılmış bir dosyada kayıt altına alınmaktadır. Çalışmanın kapsamına göre bir veya daha fazla sayıda araştırmacı tarafından yürütülen ve genellikle birkaç haftalık çalışma sürecinin sonunda elde edilen kritik olaylar, gerçekleşme veya bahsedilme sıklıklarına, hangi soruna bağlı olduklarına, hangi unsurlarla bağlantılı olduklarına ve benzeri kriterlere göre kategorilere ayrılmaktadır. Bu şekilde bir soruna yol açan başlıca nedenler, bunların bağlantılı olduğu diğer unsurlar tespit edilmekte; sistem ya da hizmet iyileştirmeleri için öncelikle ele alınması gereken konu başlıkları ortaya konulmuş olmaktadir.

Hizmet pazarlaması alanında kritik olaylar tekniğini uygulayan birçok araştırmacı, açık uçlu soru formları kullanarak müşterilerin daha önce yaşamış oldukları olumlu ve olumsuz olayları kısa hikâyeler şeklinde aktarmalarına olanak sağlamakta, bu şekilde hizmet sunumunda ortaya çıkan başlıca sorunları tespit edebilmektedir. Bu yolla müşterilerin en iyi hatırladıkları geçmiş deneyimleri ve bu deneyimlerini olumlu veya olumsuz yönde etkileyen hususların tespiti mümkün olmaktadır.

Kritik olaylar yöntemi, müşterilerarası ilişkilerin incelendiği az sayıda çalışmada da kullanılmıştır. Örneğin, bu tekniği kullanarak 15 farklı hizmet alanı ile ilgili 75 katılımcidan toplam 142 kritik olay elde eden Zhang, Beatty ve Mothersbaugh (2010), müşterilerarası etkileşimlerde olumlu veya olumsuz etkiye sahip olan ana hususların, doğrudan ve dolaylı olmak üzere iki alt boyuta sahip olduğunu tespit etmiştir. İlgili araştırmacılar bu etkileşimlerin: hizmet deneyiminin merkezinde, ilave ve ilgisiz olmak üzere üç kategoriye ayrılabileceğini; farklı hizmet alanları için bu kategorilerin değişebileceğini göstermişlerdir. Yan ve Lotz (2004) tarafından gerçekleştirilen bir 
başka araştırmada 97 katılımcıdan elde edilen ve farklı hizmet alanlarına ait toplam 70 kritik olay incelenerek, müşteri şikâyet etme eğiliminin diğer müşterilerin mekândaki mevcudiyetlerinden etkilenip etkilenmediği ele alınmıştır. Sonuçlara göre, diğer müşterilerin hizmet alanındaki fiziki mevcudiyeti, müşterilerin şikâyet etme eğilimlerini arttırıcı bir etkiye sahiptir.

\section{Alan Araştırması}

Bu çalışmanın alan araştırması, Antalya'ya gelen yerli turistlere yönelik yarı-yapılandırılmış bir yüzyüze anket uygulamasına dayanmaktadır. Veri, yerel bir seyahat acentesi ile işbirliği kurularak, kolayda örneklem yoluyla Mayıs-Haziran 2015 döneminde Antalya, şehir turuna katılan 206 katılımcıdan elde edilmiştir. Sezer ve Şahin'in (2015) belirttiği gibi kritik olaylar tekniğinde her ne kadar Twelker (2003), asgari olay sayısını 50 olarak önermekte ise de bu sayı araştırma sorusunun karmaşıklığına göre değişebilmekte olup, belli bir tutarlılığa ulaşıldıktan sonra veri toplama çalışmasının durdurulması önerilmektedir. Bu çalışmada katılımcılardan yeterli çeşitlilik ve sayıda kritik olay edinildiği için 206 anket geri dönüşü araştırma amaçlarının sağlanması için yeterli kabul edilmiştir.

\section{Soru Formu}

Soru formunda katılımcıların başlıca demografik özelliklerini (cinsiyet, yaş, medeni durum, çocuk sayısı ve meslek) ortaya koyan kapalı uçlu soruların yanı sıra, katılımcıların 'uçak yolculukları esnasında diğer yolculardan kaynaklanan nedenlerle yaşadikları olumlu ve olumsuz hatıralarını kısa bir biçimde yazmaları' için açık uçlu bir soru da yer almıştır. Yöneltilen bu soruya katılımcıların en az bir, en fazla üç deneyimini yazmasına olanak sağlayacak, iki ayrı sütundan (olumlu deneyim - olumsuz deneyim olmak üzere) oluşan bir alan bırakılmıştır.

\section{Analiz}

Katılımcıların vermiş oldukları cevaplar araştırmacı tarafından okunarak, ilk aşamada olumlu ve olumsuz deneyimler olmak üzere iki ana kategori altında sınıflandırılmıştır. Bu aşamada diğer müşterilerle ilgisi bulunmayan ve genellikle uçak şirketi veya tanıdık kişilerle (arkadaş, akraba, iş arkadaşı gibi) ilgili olan deneyimler değerlendirme dışı bırakılmıştır. Bu aşama sonucunda elde edilmiş olan 'olumlu' kritik olay sayısı 157, 'olumsuz' kritik olay sayısı 321 olmuştur. İzleyen aşamada, hem olumlu hem de olumsuz deneyimler uçuş deneyiminin üç temel aşamasından (biniş-uçuş-iniş) hangisinde gerçekleşmiş oldukları esas alınarak bir alt kategoride daha ayrıma tabi tutulmuştur (Şekil 1).

Tematik kodlamanın kontrol edilmesinde, çalışma hakkında önceden bilgi sahibi olmayan ve birbirinden bağımsız değerlendirme yapacak olan iki akademisyenin görüşünden ve NVivo 10.0 programından yararlanılmıştır. Bu amaçla olumlu deneyimlerin (157 adet) ve olumsuz deneyimlerin (321 adet) \%10'una denk gelen say1da, yani 15 adet olumlu ve 32 adet olumsuz biniş-uçuş-iniş aşamasındaki deneyime ait ifade akademisyenler tarafından önerilen kodlarla eşleştirilmiştir.

İlgar ve İlgar (2014), bu tür çalışmalarda asgari \%70 düzeyinde bir güvenirlik yüzdesine ulaşılması ve araştırmacı tarafından kodlanan verilerin tutarlılığının [Görüş Birliği / (Görüş Birliği + Görüş Ayrılı̆̆1) x 100] formülü kullanılarak hesaplanması gerektiğini (Miles ve Huberman 1994) belirtmektedir. Bu bağlamda, yapılan araştırmada ilgili formül kullanılarak, akademisyenlerin \%88 oranında görüş birliğinde oldukları tespit edilmiştir. NVivo 10.0 programı ve uzmanların görüşlerinden elde edilen sonuçlar, tematik kodlamanın kabul edilebilir olduğunu göstermektedir.

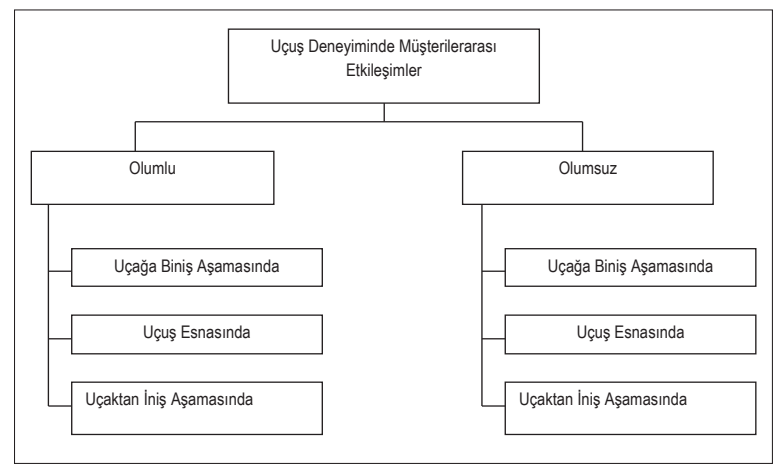

Şekil 1. Uçuş Deneyiminde Müşterilerarası Etkileşim Aşamaları 


\section{ARAŞTIRMA BULGULARI}

\section{Katılımcıların Demografik Özellikleri}

Katılımcıların \%54,9'u kadın (113 kişi); \%45,1'i erkektir (93 kişi). Yaş gruplarına bakıldı̆̆ında büyük bir bölümünün 26-35 yaş arası (113 kişi; \%54,9) kişilerden oluştuğu, bu grubu 18-25 (48 kişi; \%23,3) ve 34-41 yaş (25 kişi; \%12,1) aralığındaki katılımcıların takip ettiği görülmektedir. Medeni durum açısından katılımcıların çoğunluğu evlidir (144 kişi; \%69,9). Yirmi yedi katılımcının 18 yaş altında çocuğu bulunmaktadır. Meslek gruplarında özel sektör (91 kişi; \%44,2), kamu (50 kişi; \%24,3) ve serbest meslek çalışanları (25 kişi; $\% 12,1$ ) önde gelmektedir (Tablo 1).

\section{Uçuş Deneyiminde Rol Oynayan Müşterilerarası Etkileşimler}

\section{Olumlu Doğrudan ve Dolaylı Etkileşimler (Biniş-Uçuş-İniş Aşamalarında)}

Katılımcıların ifade ettiği toplam 478 kritik olay içerisinde 157 'si $(\% 32,8)$ olumlu müşterileraras1 etkileşimlere yöneliktir. 'Olumlu' deneyimler incelendiğinde \%26,1'inin (41 adet) uçağa biniş; \%59,2' sinin (93 adet) uçuş; \%14,7'sinin (23 adet) ise uçaktan iniş aşamasında gerçekleşmiş olduğu görülmüştür. Uçuş esnasında yaşanan olumlu deneyimlerin diğer aşamalara kıyasla fazla sayı-

Tablo 1. Demografik Özellikler

\begin{tabular}{llrr}
\hline & & Frekans & Yüzde (\%) \\
\hline Cinsiyet & Kadın & 113 & 54,9 \\
& Erkek & 93 & 45,1 \\
\hline Yaş & $18-25$ yaş arası & 48 & 23,3 \\
& 26-33 yaş arası & 113 & 54,9 \\
& 34-41 yaş arası & 25 & 12,1 \\
& $42-49$ yaş arası & 7 & 3,4 \\
& 50 yaş ve üzeri & 13 & 6,3 \\
\hline \multirow{2}{*}{ Medeni Durum } & Evli & 144 & 69,9 \\
& Bekâr & 62 & 30,1 \\
\hline \multirow{2}{*}{ Meslek } & Özel sektör çalışanı & 91 & 44,2 \\
& Kamu çalışanı & 50 & 24,3 \\
& Serbest meslek & 25 & 12,1 \\
& İşveren & 15 & 7,3 \\
& Öğrenci & 11 & 5,3 \\
& Diğer & 14 & 6,8 \\
\hline
\end{tabular}

da olduğu dikkat çekmektedir. Elde edilen ana ve alt kategoriler Şekil 2'de yansitılmıştır.

Uçağa biniş esnasındaki olumlu etkileşimlerin (BO) büyük bir bölümü (\%20'si) yardımlaşmalardan kaynaklanmaktadır. Kabin bagajının yerleştirilmesi, yer değiştirilmesi, sıra verilmesi, eşya taşınması ve benzeri şekillerde bir başka yolcunun yardım ve desteğinin alınmış olması katılımcıların çoğunu etkilemiştir. Bazı katılımcılar bu konudaki görüşlerini şu şekilde ifade etmiştir:

K021: “Bebeğimiz olduğu için bilet kontrolü esnasında yolculardan birisi sıranın başına geçebilmemiz için yardımcı oldu."

K130: "Arkadaşımla koltuk numaralarımız farklı olmasına karşın, rica ettiğimiz yolcu yerini değiştirdi."

Uçuş esnasındaki olumlu etkileşimler (UO) en fazla sayıda kritik olayın ortaya konulduğu alandır. Ancak bu hususta katılımcılar arasındaki görüş farklılıkları dikkat çekmektedir. Katılımcıların bir bölümü $(\% 12,1)$ diğer yolcularla sohbet etmenin, yeni dostluklar edinmenin $(\% 7,6)$ ve güler yüzlü kişilerle yolculuk etmenin $(\% 5,7)$ uçuş deneyimlerini olumlu yönde etkilediğini ifade ederken; bir kısmı $(\% 9,5)$ yolculuk ettikleri kişilerin kendileri ile konuşmamasından, kitap, gazete ve benzeri ile meşgul olmasından memnuniyet duymaktadır. Katılımcıların uçuş esnasındaki olumlu deneyimlerine yönelik bazı ifadeleri şu şekildedir:

K004: “ilk kez uçağa bindiğimde çok korktuğumu anlayan yanımdaki yolcu benimle muhabbet ederek, heyecanımı yatıştırmıştı."

K058: "Yanımda oturan yolcu bana çay ismarlad1."

K150: "Tanıştığım yolcu ile hoşça sohbet etmek hoşuma gitmişti."

Uçaktan iniş esnasındaki olumlu etkileşimlerin (İO) sayısı, diğer aşamalara kıyasla daha az sayıda olup $(\mathrm{N}=23)$, katılımcıların genel olarak anlayışlı $(\% 7,6)$ ve saygılı davranışlardan $(\% 5,7)$ etkilendikleri görülmektedir. Diğer başlığı altındaki kritik olaylardan birisinde katılımcı, yaşadığı ilginç olayı şu şekilde aktarmıştır: 


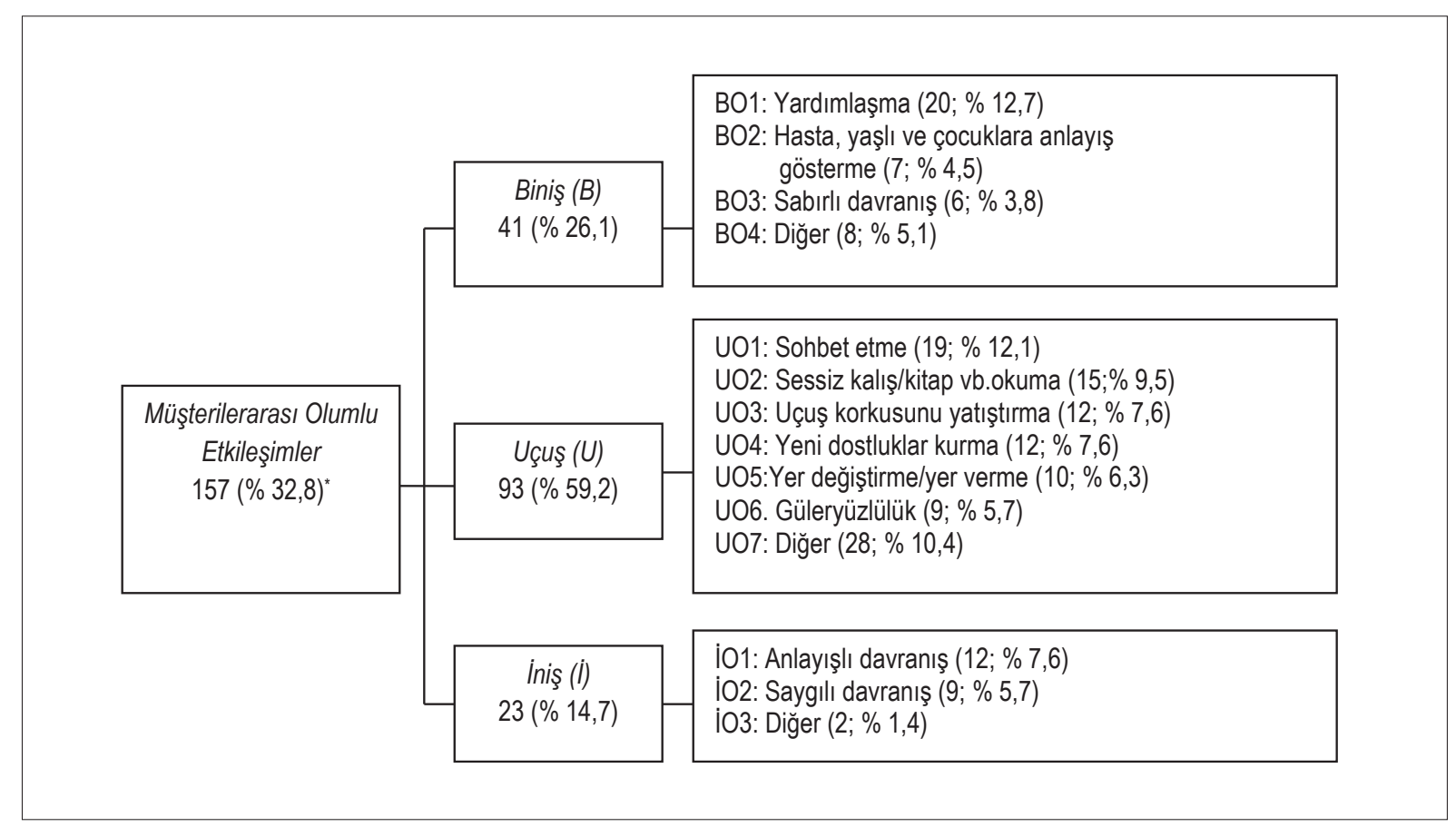

Şekil 2. Biniş-Uçuş-İniş Aşamalarında Müşterilerarası Olumlu Etkileşimler (*Toplam kritik olaylar içerisinde sadece olumlu etkileşime ait olanların sayı ve yüzdesi)

K046: “İnişe geçerken, 2-3 yaşlarındaki bir çocuğun annesine "düşüyoruz" diyerek ağlamaya başlaması bütün yolcuları güldürmüştü."

Bir başka katılımcı (K043) ise diğer yolcuların saygılı davranışlarına dikkat etmiş ve izlenimlerini "Uçaktan inerken bazılarının yaşlılara yardımcı olması hoşuma gitmişti" şeklinde ifade etmiştir.

\section{Olumsuz Doğrudan ve Dolaylı Etkileşimler (Biniş-Uçuş-İniş Aşamalarında)}

Elde edilen sonuçlara göre toplam 478 kritik olay içerisinde 321'i $(\% 67,1)$ olumsuz müşterileraras1 etkileşimlere aittir. 'Olumsuz' deneyimlerin \%32,4'ü (104 adet) uçağa biniş; \%60,1'i (193 adet) uçuş esnasında; sadece \%7,5'i (24 adet) uçaktan iniş aşamasında yaşanmıştır. Bu durum olumsuz uçuş deneyimlerinin çoğunun uçuş esnasında gerçekleştiğini göstermektedir. Elde edilen ana ve alt kritik olay kategorileri Şekil 3'te gösterilmiştir.

Uçağa biniş esnasındaki olumsuz etkileşimlerin (BZ) çoğunu yolcuların sabırsız davranışları $(\% 25,9)$, birbirleriyle yaptıkları kavgalar $(\% 14,4)$ ve kötü kokunun $(\% 10,6)$ yol açtığı rahatsızlıklar oluşturmaktadır. Bazı yolcuların yavaş davranışları diğer yolcular üzerinde rahatsızlığa (K116: “Bir uçuşumda yolcular biniş esnasında o kadar yavaş davrandılar ki, uçuş rötarlı başladı."); bazı yolcuların acele davranışları ise hatalara ve gerilimlere yol açmaktadır (K054: “Koltuk numaram pencere kenarı idi. Fakat benden önce gelen yolcu oturmuştu, kaldıramadım."; K123: “Biniş sırasındayken iki yolcu arasındaki kavgayı dinlemek zorunda kaldım, oldukça sıkıntı duydum."). Diğer yolcuların saygısız davranışları da deneyimi olumsuz yönde etkilemektedir (K157: “Bagaja eşya vermemek için hacimli valizleri dahi baş üstü dolaplarına koyduklarından, montumu koyacak yer bulamamıştım.").

En fazla sayıda olumsuz deneyimin yaşandığ aşama, uçuştur. Uçuş esnasında yolcuların yüksek sesli konuşmalarından (\%10,3), çocuk veya bebek ağlamalarından (\%6,5), koltuk yatırmalarından (\%6) ve benzeri davranışlarından ötürü rahatsızlık duyulduğu görülmektedir. Bu kapsamdaki olumsuz etkileşimlerden (UZ) bazıları şu şekilde ifade edilmiştir: 


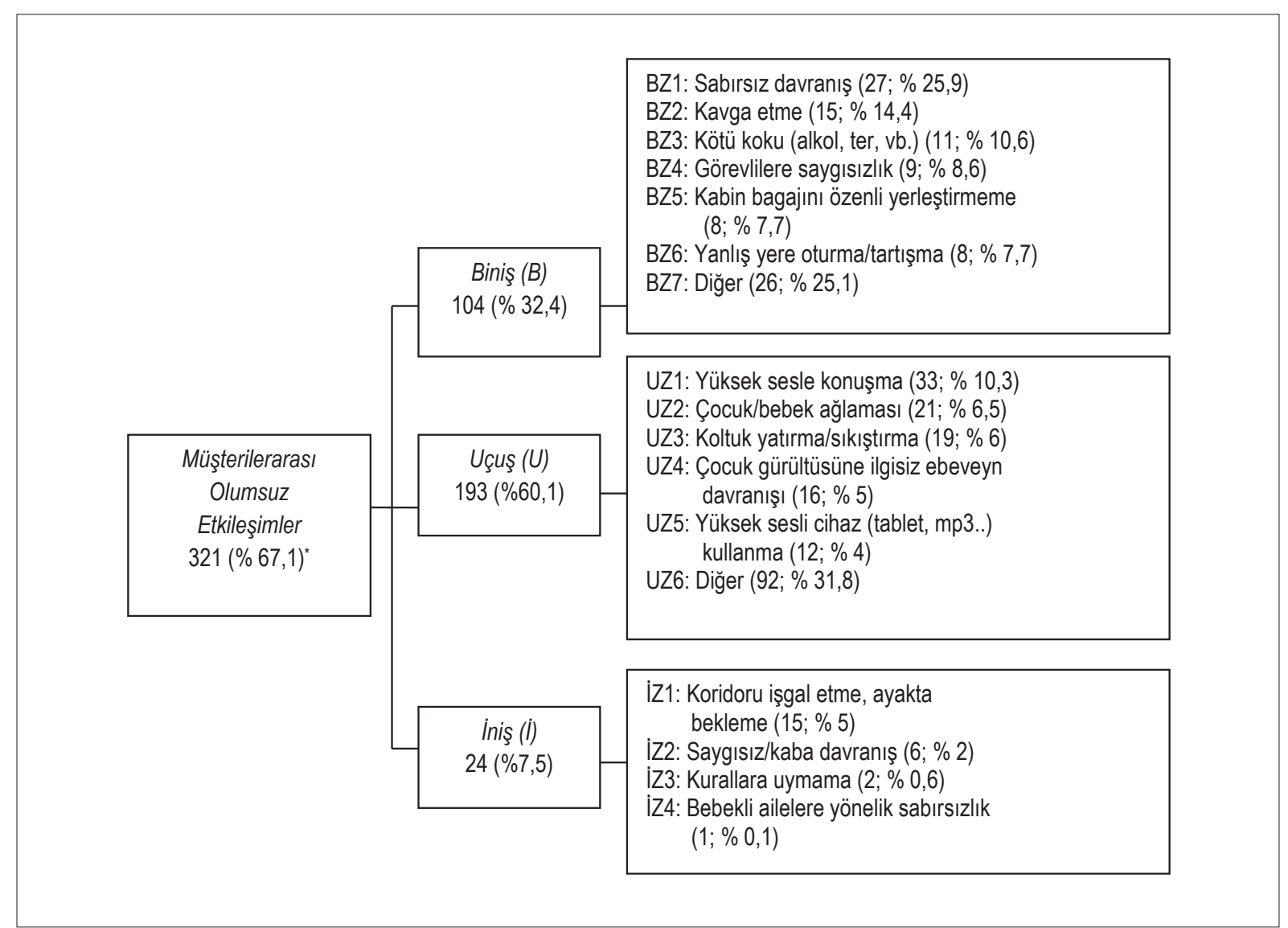

Şekil 3. Biniş-Uçuş-İniş Aşamalarında Müşterilerarası Olumsuz Etkileşimler ( ${ }^{*}$ Toplam kritik olaylar içerisinde sadece olumsuz etkileşime ait olanların sayı ve yüzdesi)

K024: “Yan koltukta oturan yolcu uyurken baş1nı ortak koltuk aralığımızdaki yere yaslayarak beni rahatsız etti."

K028: "Uçuş süresince iki arkadaş aralarında yüksek sesle ve kaba bir biçimde konuştular."

K062: "Yanımda oturan yolcu, sanırım uçuş korkusundan olsa gerek çok miktarda konyak içerek, sarhoş oldu."

K138: “Uçuşta gürültü yapan çocuklar nedeniyle çok rahatsız olmuştum."

K199: “Yanıma oturan bebekli bayan sürekli ağlayan çocuğu susturmak yerine, çok bunald1ğını söyleyerek, çocuğu tutmamı istedi. Uçuş boyunca ağlayan bebek kucağımdaydı."

Uçaktan iniş esnasındaki olumsuz etkileşimlerin (IZ) büyük bölümünün de uçağa biniş aşamasında olduğu gibi saygısız davranışlar oluşturmaktadır (koridoru işgal etme/ ayakta durma, kaba davranış ve kurallara uymama gibi). Bunlardan bazıları şu şekilde ifade edilmiştir:

K166: "Uçak indikten 1-2 dakika sonra "hala açılmadı mı bu kapılar?" diye bağıran bir yolcu nedeniyle çok sinirlenmiştim."

K178: "İniş için uçağın koridorunda yığılanlar ve yaşanan itiş kakış nedeniyle rahatsız oldum".

K115: “Uçak yere iner inmez yolcuların büyük bir bölümü ayaklandı, eşyalarını almaya ve koridorda yı ğılmaya başladılar."

Uçuş deneyiminin her aşamasında yolcuların deneyimlerini olumlu ya da olumsuz yönde etkileyen kritik olayların ortaya konulmuş olması, gerek teorik gerekse pratik açıdan kayda değer sonuçlar ortaya koymuştur. İzleyen bölümde elde edilen bu sonuçlara yönelik çıkarımlar sunulmuştur. 


\section{SONUÇ VE ÖNERILER}

Turizm işletmelerinin artan rekabete karşı koyabilmeleri açısından unutulmaz müşteri deneyimleri yaratabilmeleri bir koşul hale gelmiştir. Schmitt'in (2003) önemle üzerinde durduğu gibi günümüzde müşterilere zengin, mutluluk veren ve unutulmaz deneyimler sunmak, müşteri memnuniyetinin ve sadakatinin de garantilenmesi anlamına gelmektedir. Bu açıdan işletmelerin müşteri davranışlarını ve müşterilerin diğer müşteriler üzerindeki etkisini anlayabilmeleri gereklidir. Bu çalışmada, turizm sektörünün en önemli alanlarından biri olan havayolu işletmeciliği ele alınarak, müşterilerin uçuş deneyimlerinin her aşamasında etkili olan müşterilerarası etkileşimler ortaya konmuştur.

\section{Kuramsal Çıktılar}

Gerçekleştirilen araştırma sonucunda uçak yolculuklarında diğer müşterilerle kurulan etkileşimlerden kaynaklanan olumsuz deneyimlerin olumlulara kıyasla daha çok hatırlandığı; uçağa biniş ve iniş aşamasında yaşanan hem olumlu hem de olumsuz müşterilerarası etkileşimlerin sayısının, uçuş esnasındakilerden az olduğu tespit edilmiştir.

Bu araştırmada elde edilmiş olan sonuçların, turizm alanyazınında yapılmış olan bazı çalışmalarla örtüştüğü görülmektedir. Örneğin, Wu'nun (2007) Tayvan'da yapmış olduğu bir çalışmada yurtdışından Taipei'ye henüz gelmiş turistlerin yolculukları esnasında yaşamış oldukları müşterilerarası etkileşimler beş faktör altında toplanmıştır. Mevcut çalışmada tespit edilmiş olan kategorilerden bazıları bu faktörlerle uyumludur. Wu'nun 'şiddet olayları' faktörü altında topladığı diğer müşterilerle kavga ve koltuk/masa s1kıştırma olayları; mevcut çalışmadaki olumsuz deneyimlerin uçağa biniş (kavga etme) ve uçuş (koltuk yatırma/sıkıştırma) kategorilerinde bulunmaktadır. 'Saygısız olaylar' faktöründe yer alan bazı hususlar ise bu çalışmadaki olumsuz uçuş aşaması etkileşimlerinde (yüksek sesle konuşma, çocuk gürültüsüne ilgisiz ebeveynler) konumlanmıştır. Araştırmacının 'protokol ve sosyal olaylar' faktöründe yer verdiği sohbet etme ve sosyalleşmeye ilgi gibi hususlar ise bu ça- lışmada olumlu-uçuş aşaması etkileşimlerde söz konusudur (sohbet etme, güleryüzlülük ve yeni dostluklar kurma gibi).

Grove ve Fisk'in (1997) Florida'daki cazibe merkezlerini ziyaret eden turistlere yönelik yaptığ çalışmada ise 'sosyallikle ilgili olaylar' kategorisinde yeni kişilerle tanışmanın olumlu müşterilerarası etkileşimler arasında kabul edildiği belirlenmiş olup, mevcut çalışmanın uçuş esnasındaki olumlu etkileşimler kategorisinde bu hususun yer aldığı görülmektedir. Bu sonuç, bireylerin zihninde yer eden, unutulmaz turist deneyimlerinde sosyalleşmenin önemli bir rol oynadığını ve turistlerin yeni kişilerle tanışmaktan genellikle olumlu yönde etkilendiklerini yansıtmaktadır. Özet olarak, turizm sektörünün hızla gelişen hizmet alanlarından biri olan havayolu işletmeciliğinde müşterilerarası etkileşimlerin araştırılmış olduğu bu çalışmada tespit edilen birçok kritik olay, uluslararası alanyazında farklı ülkelerde ve turizm deneyimlerinde ortaya konulmuş olan olaylarla örtüşmektedir. Aynı zamanda Türkiye turizm ve seyahat işletmeciliği kapsamında ilk kez havayolu işletmeciliğinde müşterilerarası ilişkileri ele alan bir araştırmanın gerçekleştirilmiş olması, ilgili alanyazına katkı sağlamıştır.

\section{Uygulamaya Yönelik Çıktılar}

Yapılan durum analizi havayolu işletmelerinin özellikle uçuş esnasında müşterilerle yakından ilgilenmesi gerektiğini, zira olumsuz müşterilerarası etkileşimlerin en fazla bu aşamada gerçekleştiğini göstermektedir. Elde edilen bu sonuç daha önce havayolu işletmelerden kaynaklanan bazı hizmet hataları yaşamış müşterilerin karşılaştıkları yeni sorunlara yönelik toleranslarının düşük olmasından da (Smith ve Bolton 2002) kaynaklanmış olabilir. Nitekim yapılan araştırmalara göre müşteriler işletme kaynaklı hayal kırıklıklarını bir kontrol ve inisiyatif kaybı olarak görmekte, daha sonra yapacakları satın almalarda ilgili işletmeye yönelik yüksek risk algısı geliştirmektedirler (Zeelenberg, Van Dijk, Manstead ve Der Pligt 1998). Bu sebeple havayolu işletmelerinin müşteri memnuniyetini ve sadakatini sağlamak amacıyla özellikle uçuş esnasındaki olumlu müşteri-personel ve müşteri-müşteri et- 
kileşimlerini teşvik etmeleri, bu amaçla farklı uygulamalar geliştirmeleri gerektiği açıktır.

Müşterilerarası etkileşim her ne kadar işletmelerin üzerinde tam kontrol sahibi oldukları bir konu değilse de ortaya koyduğu sonuçlar açısından müşteri memnuniyeti, işletme imajı ve başarısı üzerinde doğrudan bir etkiye sahiptir. Ayrıca Huang'ın da (2008) belirttiği gibi müşteriler diğer müşterilerden kaynaklanan hizmet hatalarını işletmelerin sorumluluğu altında kabul etmektedir. Eğer işletmeler arzu edilmeyen davranışlar gösteren müşterilerin bu davranışlarını engelleyebilir ya da kontrol edebilirlerse, işletme imajının desteklenmesi ve diğer müşterilerin memnuniyetsizliklerinin telafi edilebilmesi söz konusu olabilir. Bu nedenle ortaya çıkan olumsuz müşterilerarası etkileşimlerin anında farkına varılarak, en kısa sürede çözüme kavuşturulması önemli bir husustur. Havayolu personelinin görmezlikten geldiği veya çözüme kavuşturmakta yetersiz kaldı ̆̆ı müşterilerarası anlaşmazlıklar, çeşitli müşteri mağduriyetlerine yol açabilir. Bu tür olayların medyaya yansıması veya hukuki ortama taşınması halinde işletme imajının zarar görmesi, potansiyel ve sadık müşterilerin davranışsal niyetlerinin olumsuz şekilde etkilenmesi mümkündür.

Bu gibi durumları engellemek amacıyla izlenebilecek stratejiler arasında kurumsal açıdan uygun görülmeyen müşteri davranışlarının neler olduğunun açık bir biçimde tanımlanması, bu tür davranışların yol açacağı olumsuzluklar ve olası yaptırımlar hakkında müşterilere detaylı bilgi sunulması sayılabilir. Aynı zamanda kurumsal prensiplerin müşteriler tarafından açık şekilde anlaşılmasına yönelik olarak görsel ve yazılı medya araçlarından etkin şekilde yararlanılması düşünülebilir. Bu şekilde havayolu işletmeleri ile müşterileri arasında kurulacak olan yakın iletişim ve ortak bakış açısı sayesinde gerek işletmemüşteri, gerekse müşterilerarası anlaşmazlıkların ortaya çıkmaması sağlanabilir.

Havayolu işletmeleri esas alındığında, müşteri davranışlarının gözlemlenerek arzu edilen ve edilmeyen davranışların tespit ve kontrol edilmesi, diğer turizm işletmelerine kıyasla daha olasıdır. Nitekim bu işletmelerin özellikle kabin eki- bi ve yer hizmetleri personeli iş sürecinin birçok aşamasında yolcularla yakın temas ve iletişim halindedir. Olumsuz müşterilerarası etkileşimlerin ortaya çıktığı anlarda doğrudan müdahale etme şansına sahip olan bu personel, aynı zamanda benzer sorunların tekrarlanmaması açısından işletmeye görüş bildirme ve yönetim stratejilerine yön verme gücüne de sahiptir. Bu bağlamda, havayolu işletmelerinde yolcu deneyiminin zenginleştirilmesi, uçuşların planlanan ve istenilen şekilde gerçekleştirilebilmesi açısından işletme personelinin hizmet kalitesini arttırmaya yönelik motivasyon ve katılımcılığının yükseltilmesi gerekmektedir. Bunun yanı sıra müşteri-odaklı (tercihen mülakat şeklinde) araştırmalar yapılarak, işletmenin daha önce göz ardı ettiği bazı hizmet sunum aşamalarındaki uygulamalar gözden geçirilmelidir. Bu tür araştırma-geliştirme çalışmaları sayesinde müşteri memnuniyetini arttıran farklı ve yenilikçi uygulamalar hayata geçirilerek, diğer havayolu işletmeleri karşısında rekabet avantajı elde edilebilir.

\section{Çalışmanın Kısıtları ve Gelecek Çalışmalara Öneriler}

Bu çalışmanın, diğer çalışmalarda da olduğu gibi birtakım kısıtları bulunmaktadır. Bunlardan ilki uçuş deneyimlerini şekillendiren hususların tespiti amaciyla kullanılan kritik olaylar tekniğinin kendine özgü yapısından kaynaklanmaktadır. Çalışmaya katılan kişilerden geçmiş uçuş deneyimlerini temel alarak, bu deneyimlerini olumlu ve olumsuz yönde etkileyen olayları hikâyeleştirmeleri istenmiş olduğundan, elde edilmiş olan cevaplar, katılımcıların anlık hatırlamalarına bağlıdır. Bunun yanı sıra elde edilen bulgular, araştırmacı tarafından tespit edilmiş olan kodlara ve kategorilere bağlı olarak şekillenmiştir. Başka çalışmalarda farklı sonuçların alınabilmesi bu sebeple mümkündür. Durum analizi niteliğindeki bu nitel çalışmadan elde edilen bulgular genellenebilir olmadığından, ileride yapılacak olan benzer konudaki çalışmalarla elde edilecek olan sonuçların alanyazın katkısını arttırması muhtemeldir.

Ayrıca yapılan alan araştırmasında kullanılan soru formunda katılımciların seyahat nedenlerine, uçuş tecrübelerine ve diğer demografik özel- 
liklerine yönelik sorulara yer verilmediğinden, farklı analizler gerçekleştirilememiştir. Bu da çalışmanın kısıtları arasında görülebilir. Nitekim Lovelock ve Wirtz (2004) tarafından önerildiği gibi olumlu veya olumsuz müşterilerarası etkileşimlere sebep olan müşterilerin başlıca özellikleri tespit edilerek, profili ortaya konabildiği takdirde, turizm sektörünün farklı alanlarında gözlemlenen müşteri davranışlarının daha iyi anlaşılabilmesi ve bu davranışların işletmeler tarafından istenen şekilde yönlendirilebilmesi mümkün olabilir. Son olarak ileride yapılacak olan çalışmalarda turizm sektörünün farklı alanlarında (konaklama, yeme-içme, rekreasyon gibi) söz konusu olan müşterilerarası etkileşimlerin de araştırılarak, bu etkileşimlerin memnuniyet, davranışsal niyet ve sadakat gibi değişkenlerle ilişkisinin incelenmesi tavsiye edilebilir.

\section{KAYNAKÇA}

Baker, J. ve Cameron, M. (1996). The Effects of the Service Environment on Affect and Consumer Perception of Waiting Time: An Integrative Review and Research Propositions, Journal of the Academy of Marketing Science, 24 (4): 338-349.

Bitner, M. J. (1992). Servicescapes: The Impact of Physical Surroundings on Customers and Employees, Journal of Marketing, 56: 57-71.

Bitner, M. J., Booms, B. H. ve Mohr, L. S. (1994). Critical Service Encounters: The Employee's Viewpoint, Journal of Marketing, 58: 95-106.

Brocato, E. D., Voorhees, C. M. ve Baker, J. (2012). Understanding the Influence of Cues From Other Customers in the Service Experience: A Scale Development and Validation, Journal of Retailing, 88 (3): 384-398.

Davies, B., Baron, S. ve Harris, K. (1999). Observable Oral Participation in the Servuction System: Toward a Content and Process Model, Journal of Business Research, 44: 4753.

Flanagan, J. C. (1954). The Critical Incident Technique, Psychological Bulletin, 51 (4): 327-358.

Grove, S. J. ve Fisk, R. P. (1997). The Impact of Other Customers on Service Experiences: A Critical Incident Examination of "Getting Along", Journal of Retailing, 73 (1): 63-85.

Huang, W-H. (2008). The Impact of Other-Customer Failure on Service Satisfaction, International Journal of Service Industry Management, 19 (4): 521-536.

İlgar, S. C. ve İlgar, M. Z. (2014). Nitel Veri Analizinde Bilgisayar Programları Kullanılması, İstanbul Sabahattin Zaim Üniversitesi (İZ̈̈) Sosyal Bilimler Dergisi, 5: 31-78.

Kim, N. ve Lee, M. (2012). Other Customers in a Service Encounter: Examining the Effect in a Restaurant Setting,
Journal of Services Marketing, 26 (1): 27- 40.

Langeard, E., Bateson, J., Lovelock, C. ve Eiglier, P. (1981). Marketing of Services: New Insights from Consumers and Managers, Working Paper, Rapor No: 81-104. Cambridge, MA: Marketing Sciences Institute.

Lovelock, C. H. ve Wirtz, J. (2004). Service Marketing. (5. Basim), Englewood Cliffs: NJ, Prentice-Hall, USA.

Martin, C. L. ve Pranter, C. A. (1991). Compatibility Management: Roles in Service Performers, The Journal of Services Marketing, 5 (2): 43-53.

McGrath, M. A. ve Otnes, C. (1995). Unacquainted Influencers: When Strangers Interact in the Retail Setting, Journal of Business Research, 32: 261-272.

Miao, L. ve Mattila, A. S. (2013). The Impact of Other Customers on Customer Experiences: A Psychological Distance Perspective, Journal of Hospitality $\mathcal{E}$ Tourism Research, 37 (1): 77-99.

Miles, M. B. ve Huberman, M. (1994). Qualitative Data Analysis: An Expanded Sourcebook. (2. Basim), Tousand Oaks, CA:Sage Yayınları.

Moore, R., Moore, M. L. ve Capella, M. (2005). The Impact of Customer-to-Customer Interactions in a High Personal Contact Service Setting, Journal of Services Marketing, 19 (7): 482-491.

Mourali, M. (2003). Customer-to-Customer Interactions and Their Effects on Service Evaluation: A Role Theoretic Perspective, Working Paper.

Nicholls, R. (2011). Customer-to-Customer Interaction (CCI): A Cross-Cultural Perspective, International Journal of Contemporary Hospitality Management, 23 (2): 209- 223.

Otto, J.E. ve Ritchie, J. R B. (1996). The Service Experience in Tourism, Tourism Management, 17 (3): 165-174.

Öztürk, S. A. (2000). Hizmet Kalitesi Ölçümünde Yeni Bir Yaklaşım: Kritik Olaylar Tekniği, Anatolia: Turizm Araştırmaları Dergisi, Prof. Dr. Hasan Olalı Özel Sayısı, 11: 57-68.

Palmer, A. (2005). Principles of Services Marketing. (4. Basım), McGraw Hill Education, UK.

Pine, B. J. ve Gilmore H. J. (1999). The Experience Economy: Work is Theatre E Every Business a Stage. Boston, MA: Harvard Business School Press.

Schmitt, B. H. (2003). Customer Experience Management: A Revolutionary Approach to Connecting with Your Customers. New Jersey, USA: John Wiley \& Sons, Inc., Hoboken.

Sezer, H. ve Şahin, H. (2015). Sağlık Bilimleri Araştırmalarında Güncel Bir Yaklaşım: Kritik Olaylar Tekniği, Tıp Ĕğitimi Dünyası, 44: 13-21.

Smith, A. K. ve Bolton, R. N. (2002). The Effect of Customers' Emotional Responses to Service Failures on Their Recovery Effort Evaluations and Satisfaction Judgments, Journal of the Academy of Marketing Science, 30 (1): 5-23.

Söderlund, M. (2011). Other Customers in the Retail Environment and Their Impact on the Customer's Evaluations of the Retailer, Journal of Retail ing and Consumer Services, 18: 174-182.

The Usability Body of Knowledge. (2012). http://www.usabilitybok.org/critical-incident-technique, Erişim tarihi: 30 
Ağustos 2016.

Tombs, A. ve McColl-Kennedy, J. R. (2003). Social-Servicescape Conceptual Model, Marketing Theory, 3 (4): 447-475.

Twelker, P. A. (2003). The Critical Incident Technique: A Manual for Its Planning and Implementation, $h t t p: / / w w w$. tiu.edu/psychology/Twelker/critical_incident_technique. html, Erişim tarihi: 29 Temmuz 2015.

Wu, C. H-J. (2007). The Impact of Customer-to-Customer Interaction and Customer Homogeneity on Customer Satisfaction in Tourism Service-The Service Encounter Prospective, Tourism Management, 28: 1518-1528.

Wu, C. H. (2008). The Influence of Customer-to-Customer Interactions and Role Typology in Customer Reaction, The Service Industries Journal, 28 (10): 1501-1513.

Yan, R-N. ve Lotz, S. (2004). Consumer Complaint Behavior:
Do "Other Customers" Make a Difference?, Advances in Consumer Research, 31: 491-492.

Yi, Y., Gong, T. ve Lee, H. (2013). The Impact of Other Customers on Customer Citizenship Behavior, Psychology and Marketing, 30 (4): 341-356.

Yoo, J., Arnold, T. J. ve Frankwick, G. L. (2012). Effects of Positive Customer-to-Customer Service Interaction, Journal of Business Research, 65: 1313-1320.

Zeelenberg, M., Van Dijk, W.W., Manstead, A. S. R. ve Der Pligt, J. (1998). The Experience of Regret and Disappointment, Cognition and Emotion, 12 (2): 221-230.

Zhang, J., Beatty, S. E. ve Mothersbaugh, D. (2010). A CIT Investigation of Other Customers' Influence in Services, Journal of Services Marketing, 24 (5): 389-399.

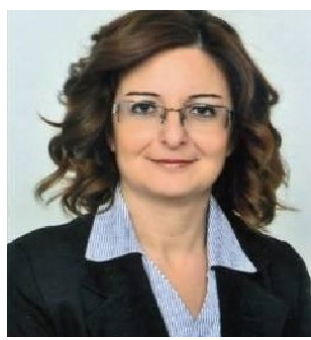

\section{Meltem CABER}

Akdeniz Üniversitesi Turizm İşletmeciliği ve Otelcilik Yüksekokulu'ndan mezun oldu (1992). Yüksek lisans derecesini Anadolu Üniversitesi'nden Turizm ve Otel İșletmeciliği dalından (2004), doktora derecesini de Akdeniz Üniversitesi'nden Turizm İşletmeciliği ve Otelcilik dalından aldı (2010). Akdeniz Üniversitesi'nde çalışmaya başladı (2005). Doçentlik unvanını Turizm alanında aldı (2014). Halen Akdeniz Üniversitesi Turizm Fakültesi'nde görev yapmaktadır. Temel çalışma alanları; turizm pazarlaması, destinasyon yönetimi ve elektronik ticarettir. 